\title{
Research on the Growth Risk of China's Small and Medium
}

\section{Enterprise}

\author{
Linjie Chen \\ Department of Business Administration, Nanjing Institute of Industry Technology \\ Nanjing 210046, China \\ E-mail: ngy001@163.com
}

Foundation item: Supported by Department of Education Jiangsu Province. (No. 2010SJB630034)

Supported by Nanjing Institute of Industry Technology. (No. YK10-05-01)

\begin{abstract}
This paper gives the definition of small and medium enterprise growth risk, and analyzes its content and categories in reviewing the relevant theoretical literature, points out the main features of growth risk of SMEs from five aspects,builds its mechanism model, and thinks the growth risk of SMEs is associated with the growth rate, its development in three stages of the potential risk, the actual occurrence and the impact. At the same time, this paper gives the risk management tactics of SMEs from the risk management objectives, procedures, control capability and so on,and specifically points out that small and medium enterprises should attach great importance to growth risks and seize growth opportunities to correctly handle the scale of development and sustainability issues, adventurous, and growth in risk management.
\end{abstract}

Keywords: SMEs, Content of growth risk, Feature, Formation mechanism model, Risk management tactics

Small and medium enterprises in the growth process will always face a number of risks, hindering development and growth, $90 \%$ of the business enterprise life longer than 3 years and can grow into successful companies listed on it is even more minimal. Sound operation and continued growth of business is full of success, if there any risk of loss of control before it is possible to make business "back to start the night before," and even complete failure. Therefore, small and medium enterprises to actively respond to the growth risk has become an urgent problem. The growth of enterprises abroad earlier theory, enterprises growth theory come from the " The theory of the Growth of the Firm " book published by Penrose (Penrose, 1959), Penrose believes that the growth of enterprises may be explained under this framework of the "enterprise resource - the capacity of enterprises enterprises growth". Internal dynamic capability development is the need for business survival, it is a business avoid being eliminated, take the initiative to "adapt" to external risk, achieve continuous improvement process. (Gu Xingshu, 2009, pp.45-47) After World War II, Western countries began to attach importance to the issue of SME growth, "growth stage" theory is one of the important results. Wen Xin Chinese scholars understand the risks from the development, growth, maturity, and decline in four different stages of growth. (Wen Xin, 2002, pp.47-48) Han Zhili analyzed the growth of high-tech enterprises in the Risk and Prevention, as well as reduce or eliminate lead to risk factors from the perspective of the value chain.(Han Zhili, 2006, pp.56-59)At present, growth risks and response measures of small and medium enterprises at home and abroad are still in the exploration.This paper attempts to further explore the growth risk of SME.

\section{The SME growth risk definition and connotation}

\subsection{The definition of the SME growth risk}

Risk in the "Oxford Advanced Learner Dictionary of Modern" in the explanation is "Possibility or chance of meeting danger, suffering loss, injury, etc". In 1895 American scholar Haynes book "Risk as an Economic Factor" in that "there is no any technical content of the risk of the term in economics and other academic fields, it means the possibility of damage or loss." Chinese scholars He Wenjiong book "Risk Management" in this definition of risk: "risk is the objective in a given case, in a specific period, which may occur in the degree of difference between the results. (He Wenjiong, 1999, pp.47-59) Clearly, this difference is the degree of actual results and expected results of the change in level. Based on the above, this article from the system theory point of view, the small and medium enterprise growth risk is defined as "SME growth risk is small and medium 
enterprises in the growth process, because the enterprise itself and the environmental conditions of uncertainty, which leads to the possibility of deviation from the actual growth speed in the enterprise and the expected target speed".

\subsection{The connotation of the SME growth risk}

SMEs in large groups, high-growth small and medium enterprises account for only $3 \%-5 \%$ ratio. The data also show that most small and medium enterprises have failed to achieve sustained growth or even close down because of growing risk not to grasp and control. (Xia Qinhua, Yi Chaohui, 2007, pp.122-126)

The connotation of the SME growth risk from four aspects.

(1) The SME growth risk is caused by the uncertainty of the enterprise itself and the environmental conditions. Uncertainty is a fundamental property of the growth risk, if all eternal, then there will be no risk of business growth, will grow according to the established goals. The uncertainty of enterprises themselves comes from unreasonable organizational structure and imperfect function. External environmental conditions is the objective conditions, which restrict growth of SMEs, its uncertainty comes from changing the objective world and human behavior.

(2) The SME growth risk depends on two variables in each constraint. One is the possibility of occurrence of deviation from the actual growth rate and forecast business target velocity, that is, the risk probability (P); Second, the size and direction of deviation from the actual growth rate and the expected business growth rate, that is, the risk of possible consequences $(\mathrm{C})$. When the actual growth rate than expected, then known as the positive deviation, whereas a negative deviation. The positive deviation is expected by SME, It belongs to the risk income, It can encourage SMEs to bravely risk, and pursue rapid growth. Therefore, the growth risk(R) is the function of the probability $(\mathrm{P})$ and the possible consequences of deviation, that is,

$$
\mathrm{R}=\mathrm{f}(\mathrm{P}, \mathrm{C})
$$

(3) SME growth risks related to its future. Has gone through the road, the results have shown, does not matter the risk. But for the future, the company has a variety of growth path. There will always be a variety of options for SMEs to choose, but no program can ensure the desired growth rate. Therefore, the growth risk and business decision-making are related. Scientific decision-making on the SME growth is of great significance.

(4) SME growth risks associated with the growth rate positive. Risk exists objectively,which is related to the objective environment and a certain space-time conditions. SME growth risks exist in the entire process of business growth. Grow faster, the greater the risk, risk and growth rate is directly proportional relationship.

\section{The SME growth risk main types and characteristics}

\subsection{The main categories of SME growth risk}

SMEs may face various risks on the growth road, according to the causes of risk classification,the growth risks can be divided into internal and external risks, see Table (1).

\subsection{The main characteristics of SME growth risk}

Characteristics of risk is objective performance of the nature of the risk and occurrence rules. Typically, small and medium enterprise growth risks are five main features.

(1) Growth risk is an objective. Changes in the objective world is eternal, and therefore the SME growth risk is objective, is not dependent on the people's will of. So, can not refuse or negative SME growth risk, must recognize the growing risk, address growing risks, and actively respond to growing risks.

(2) Growth risk is accidental, uncertain. Growth risk is objective,the occurrence of risk is inevitable for all small and medium enterprises. However, a specific SMEs, the risk of accidental events is uncertain, it is determined by random events.

(3) Growth risk is relative, variable. Small and medium enterprises in the growth process, with the resulting changes in risk factors, growth risk both increase and decrease the volume, but also a qualitative change, as well as the extinction of original risk and the emergence of new risks.

(4) Growth risk is measurable, and it is controllable. With the raise of scientific and technological level and the accumulation of experience, people continued to raise awareness of enterprise risk and risk control. Similarly, people can take various measures for small and medium enterprise growth risk by various risk factors analysis, including forecasting, estimation and control. 
(5) Growth efficiency and growth risks are integrated, symbiotic. SME growth in the financial indicators of performance are: increasing revenues, earnings continued to increase. Conversely, if companies are afraid to take development risk, conservative management, then the slow business growth, revenue increased slowly or even decline. SMEs should struggle with the risk of growing up to get the maximum benefit.

\section{The SME growth risk formation mechanism and development stages}

\subsection{The formation mechanism of SME growth risk}

(1) The constitution of SME growth risk. As with the general risk, the SME growth risk is risk factors, risk events and risk loss of three basic elements of composition. Risk factors are potential causes of events risk will cause the risks of loss. Risk events are directly caused the loss,but also to risk the possibility of the loss of the bridge into reality; Risk of loss is unintentional, unplanned and unexpected reduction in economic value, which represents small and medium growth rate dropped, revenues by extrusion.

(2) The formation mechanism mode of SME growth risk. To explain SME growth risks of the causes, according to constitute the elements of risk, where the risk formation mechanism model has been established, see Figure (1). Can be seen from the chart, risk factors increase the risk of the event or trigger,risk events leading to the risk of loss. The reason why the SME growth risk occurs is the actual growth rate of small and medium enterprises can accommodate more than the limits of its. Therefore, only small and medium enterprises to improve the ability to withstand growth rate, that is to improve growth ability, can effectively resolve the growing risks.

\subsection{The development stage of SME growth risk}

Generate the risk of SME growth, the development of performance as potential risks, and actual losses occur, and the outbreak of three stages.

(1) Potential risks stage. At this point neither injury nor the risk of their own losses, there may only lead to loss or injury trends.

(2) Actually occur stage. At this point no longer is a potential risk, but in in progress, if you do not take corresponding measures, it can lead to loss of the outbreak.

(3) Impact stage. At this point the risk is the SME growth rate of direct harm, and the SME interests of the direct loss.

\section{The SME growth risk management tactics}

Based on the foregoing knowledge and understanding of the SME growth risk, you can take a scientific approach to identify, estimate, evaluation and decision-making on SME growth risk. And select the best risk management measures to deal with growing risks to ensure that small and medium enterprises to minimize the risk of loss, to get a good growth rate and higher operating efficiency.

\subsection{Correct view of the risk of SME growth}

General business approach to risk, usually there are three attitudes, the first type is the courage to take risks, and the second is to avoid risks, the third is intermediate. So, SMEs should adopt a scientific attitude towards the growing risk.

(1) Attaches great importance to growth risks. Small and medium enterprises in the growth process, risk is everywhere and at all times, so we must attach great importance to growth risks, to analyze all possible risks, careful assessment, scientific decision-making, elaborate contingency measures.

(2) Adventurous grasp the growth opportunity. A history of the growth of small and medium enterprises is a risk of hard work, grow faster, the greater the risk. Do not take risks, is bound to a standstill behind the greater risk. Of course, adventure premise is a scientific growth risk management.

(3) Correctly handle the scale of development and sustainability. If the blind expansion of small and medium enterprises, business economics, cost structure may appear on the "smile curve", that is, as production increases, the cost not only did not continue to fall, but began to increase. To develop more "fast" and "large" are suitable? The answer to this question may be the small and medium enterprises need to consider the key strategic issues, and the largest growth risk factors. Therefore, to guard against the diversification strategy of "peach trap", to resist the temptation to blindly expand. (Gu Linglin, 2007, pp.79-81)

\subsection{Clear the SME growth risk management objectives and management programs}

(1) Risk management objectives of small and medium enterprise growth, see Figure (2).

(2) SME growth risk management process, see Figure (3). 


\subsection{Improve risk management capabilities of SMEs growth}

(1) Enhance the management capacity of the internal control. Managers in effective control of growth risk play a key role. Their attitude and daily operation style will affect the company's attitude and style. Requirements management: a dynamic continuous learning to maintain the ability to dynamically adapt to rapid sustainable development of enterprises; 2 to establish the correct concept of risk management, and staff believe in, so that risk management in all business units, functions of the agency or department to acceptable balance; 3 to effectively identify and manage risk.

(2) Standard board responsibilities, rights and interests. In the "shareholder meeting - Board of Directors Managers" agent of this basic relati, the board plays a very important role.(Chen Zitong, 2004, pp.45-46) On the growth of risk control, the active participation of a board of directors is very important. First, the introduction of independent directors to make the decisions and proceedings of the board to hear different voices, while the formation of large shareholders, the role of checks and balances and oversight; Second, we must strengthen the board of directors of the business growth of responsibility, asking them to actively participate in the main business and management, research business growth prospects.

(3) Establish a strict information disclosure system. Quality of information and disclosure mechanism will directly affect business growth and efficiency of the effect of risk control, good information and communication systems can strengthen enterprise risk management. First, the disclosure of accounting information, to strengthen accounting controls, standard corporate accounting behavior, ensure that accounting information is true, complete, timely discover and correct errors and fraud, to ensure that the relevant state laws and the implementation of internal rules and regulations; second, the disclosure of management information on a regular basis to investors and auditors to do internal control report, to be reviewed and monitored.

(4) Cultivate the right culture of risk control. First, enterprises should unite, the management and employees and between employees must ensure that the internal solidarity.Research shows that the centripetal force of business can enhance the ability to resist risks and increase business growth potential.Second,to create a learning organization, increase employee ideological and moral quality and ability to identify problems, train employees bigger picture, to ensure the implementation of internal control system effectiveness; Third, to establish a formal risk control system, a clear penalty mechanism.

\section{References}

Chen, Zitong. (2004). Risk management of SME growth. Economic Forum, (7): 45-46

Gu, Linglin. (2007). Growth of SMEs in the Risk Analysis and Control. Market Weekly• Theory, (9): 79-81.

Gu, Xingshu. (2009). Business growth research - based on the dynamic capabilities match with the outside perspective of strategic risk. Modern management science, (3): 45-47.

Han, Zhili. (2006). The risk and prevention of high-tech business growth - a value chain. Business Research, (5): 56-59.

He, Wenjiong. (1999). Risk management. Dalian: Dongbei university of finance press. 47-59.

Penrose, Edith.T. (1959). The theory of the Growth of the Firm. Newyork, JohnWiley.

Wen, Xin. (2002). The risk awareness to different stages of the innovation enterprise. Reform and Theory, (12): 47-48.

Xia, Qinhua, \& Yi, Chaohui. (2007). Venture capital for SMEs in support of growing. Trade Research, 2007 (1): $122-126$ 
Table 1. The major categories of small and medium enterprise growth risk

\begin{tabular}{|c|c|c|c|c|c|}
\hline \multicolumn{2}{|c|}{ Risk categories } & \multicolumn{4}{|c|}{ Content } \\
\hline \multicolumn{2}{|l|}{ Internal risk } & \multicolumn{4}{|c|}{$\begin{array}{l}\text { Growth risks formed by the enterprise itself ownership structure, } \\
\text { governance structure, management level, technical level and other } \\
\text { factors. }\end{array}$} \\
\hline \multirow{4}{*}{ External risk } & Natural risk & \multicolumn{4}{|c|}{$\begin{array}{l}\text { Growth risks formed by natural phenomena, physical phenomena } \\
\text { and other physical factors (such as earthquakes, tsunamis). }\end{array}$} \\
\hline & Social risk & \multicolumn{4}{|c|}{$\begin{array}{l}\text { Growth risks arising from unpredictable behavior by the company } \\
\text { (such as burglary, robbery). }\end{array}$} \\
\hline & Economic risk & \multicolumn{4}{|c|}{$\begin{array}{l}\text { Growth risks caused by the economic environment changes (such as } \\
\text { the financial crisis). }\end{array}$} \\
\hline & Political risk & \multicolumn{4}{|c|}{ Growth risks caused by the political changes (such as war). } \\
\hline \multicolumn{6}{|c|}{ Increase } \\
\hline $\begin{array}{c}\text { Risk } \\
\text { Factors }\end{array}$ & $\frac{1}{4}$ & $\begin{array}{c}\text { Risk } \\
\text { events }\end{array}$ & $\begin{array}{c}\text { Risk of } \\
\text { loss }\end{array}$ & $\begin{array}{c}\text { Actual growth rate and } \\
\text { deviation from the } \\
\text { expected growth target }\end{array}$ & $\begin{array}{c}\text { Growth } \\
\text { Risk }\end{array}$ \\
\hline & Yield & & & & \\
\hline
\end{tabular}

Figure 1. The formation mechanism mode of SME growth risk

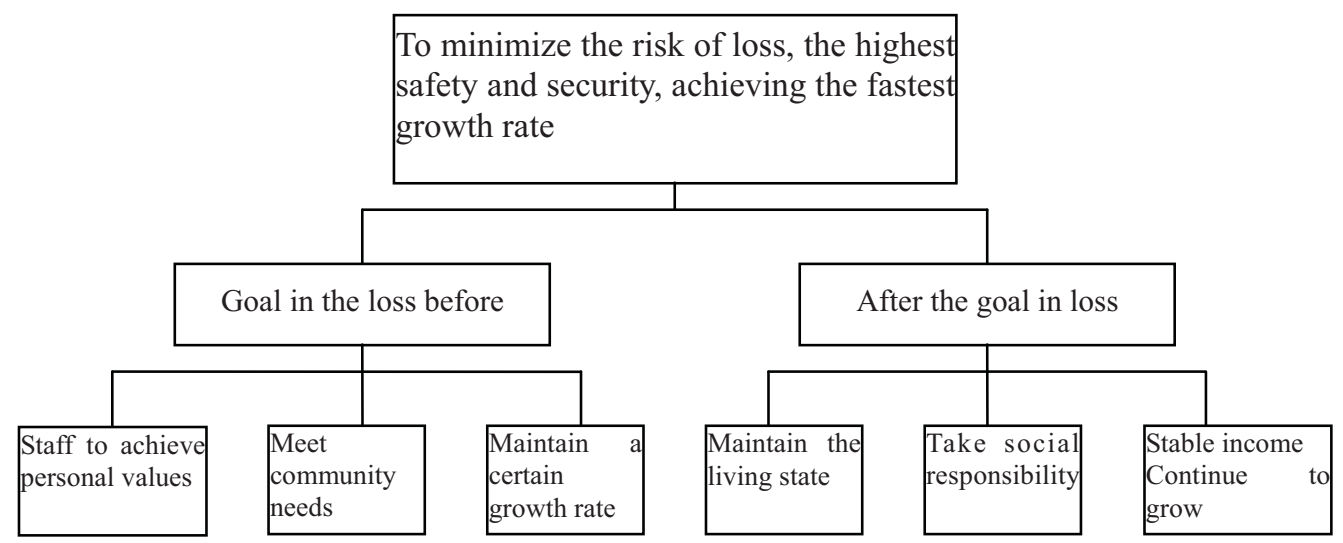

Figure 2. Risk management objectives of small and medium enterprise growth

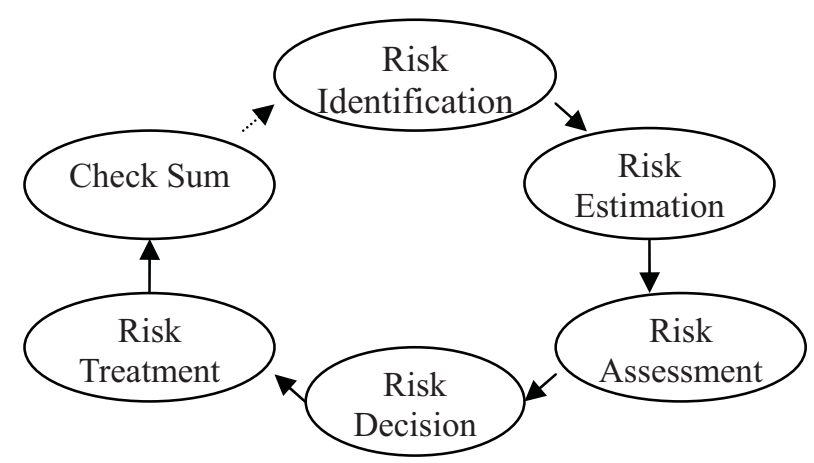

Figure 3. SME growth risk management process 